4 - ORIGINAL ARTICLE

Alimentary Tract

\title{
Hemorrhagic shock influence on colonic anastomoses in rats. Evaluation of rupture by liquid distension resistance test ${ }^{1}$
}

\author{
Influência do choque hemorrágico na anastomose de cólon em ratos. Avaliação com teste \\ de resistência à pressão de ruptura
}

\begin{abstract}
Yara Ematne Amaral Pereira', João José Fagundes ${ }^{\mathrm{II}}$, Rosana Celestina Morandini' ${ }^{\mathrm{II}}$, Maria de Lourdes Setsuko Ayrizono ${ }^{\mathrm{II}}$, Ricardo Bolzam do Nascimento ${ }^{I}$, Raquel Franco Leal ${ }^{\mathrm{I}}$, Juvenal Ricardo Navarro Góes ${ }^{\mathrm{IV}}$, Mario Mantovani ${ }^{\mathrm{V}}$, Claudio Saddy Rodrigues Coy ${ }^{\mathrm{II}}$
\end{abstract}

${ }^{\mathrm{I}}$ Fellow Master degree, Post-Graduation Program in Surgery, UNICAMP, São Paulo, Brazil.

II PhD, Assistant Professor, Digestive Tract Diseases, Surgery Department, UNICAMP, São Paulo, Brazil.

III PhD, Biologist, Trauma Surgery Investigation Laboratory, UNICAMP, São Paulo, Brazil.

Iv PhD, Full Professor, Digestive Tract Diseases, Surgery Department, UNICAMP, São Paulo, Brazil.

${ }^{v}$ PhD, Full Professor, Trauma Surgery, Surgery Department, UNICAMP, São Paulo, Brazil.

\begin{abstract}
Purpose: To evaluate the effect of hemorrhagic shock in colonic anastomoses in rats, with a rupture by liquid distension resistance test. Methods: Wistar lineage rats, averaging 90 days old and weighing from 310 to 380 grams were divided into two groups. In the first group (G1), 10 animals were submitted to colonic anastomoses in normovolemic terms and the second group (G2), of 10 animals, was submitted to colonic anastomoses in hypovolemic conditions. The shock was caused by half milliliter of blood withdrawn, every two minutes, until the value of average $50 \mathrm{mmHg}$ arterial pressure or a total volume corresponding $30 \%$ withdrawal of volemia was reached. Serum lactate dosages were carried out at the beginning and end of the procedure. The average serum lactate values at the end of the surgery were $1.91 \mathrm{mmol} / 1$ in $\mathrm{G} 1$ group and $3.69 \mathrm{mmol} / 1$ in $\mathrm{G} 2$ group (p<0.05). On the fifth postoperative day, the animals were euthanized. The anastomoses were evaluated with a rupture by liquid distension resistance test. Results: In G1, the average value of colonic rupture was $160.7 \mathrm{mmHg}$ whereas in G2 it was $152.1 \mathrm{mmHg}$ (p>0.05). Conclusion: Hemorrhagic shock, under the established conditions of this study, had no influence on colonic anastomoses in rats evaluated with the rupture by liquid distention resistance test.
\end{abstract}

Key words: Shock, Hemorrhagic. Anastomosis, Surgical. Colon. Hypovolemia. Rats.

\section{RESUMO}

Objetivo: Avaliar o efeito do choque hemorrágico em anastomoses de cólon em ratos, com teste de ruptura à distensão por líquido. Métodos: Foram utilizados ratos da linhagem Wistar, com idade aproximada de 90 dias e peso variando de 310 gramas a 380 gramas. Os animais foram divididos em dois grupos, sendo o grupo G1, composto por 10 animais submetidos à anastomose de cólon em condições de normovolemia e o grupo G2, composto por 10 animais submetidos à anastomose de cólon em condições de hipovolemia. O choque foi instalado através da retirada de meio mililitro de sangue a cada dois minutos, até que se atingissem valores de pressão arterial média (PAM) de $50 \mathrm{mmHg}$ ou volume total de retirada correspondente a 30\% da volemia. Foram realizadas dosagens séricas de lactato $(\mathrm{mmol} / \mathrm{l})$ no início do procedimento e ao término do mesmo. Os valores séricos médios de lactato ao término da cirurgia foram de $1,91 \mathrm{mmMol} / 1$ no grupo G1 e de 3,69 mmMol/1 no grupo G2 (p<0,05) No quinto dia de pós-operatório, os animais foram submetidos à eutanásia e tiveram suas anastomoses testadas por teste de resistência à pressão de ruptura à distensão por líquido. Resultados: No grupo G1, o valor médio da pressão de ruptura do cólon à distensão por líquido foi de 160,7 mmHg enquanto que no grupo G2 foi de $152,1 \mathrm{mmHg}(\mathrm{p}>0,05)$. Conclusão: A presença de choque hemorrágico, nas condições estabelecidas neste estudo, não exerce influência em anastomoses de cólon em ratos, avaliadas com teste de ruptura à distensão por líquido.

Descritores: Choque Hemorrágico. Anastomose Cirúrgica. Colo. Hipovolemia. Ratos.

1. Research performed at the Division of Experimental Surgery, Department of Surgery, Campinas University (UNICAMP), São Paulo, Brazil. 


\section{Introduction}

The growing interest in factors involved in the healing of intestinal anastomoses, is due to serious clinical repercussions secondary to the occurrence of dehiscence, increasing hospital stay and mortality. The means to avoid this important complication is part of the surgical routine. However, it does not always meet the expectations for post operative results.

However, the search for knowledge on the diverse aspects involved in intestinal healing has acquired practical importance, resulting in a great number of studies that evaluate aspects related to surgical techniques, histopathological aspects, biochemicals or biomechanics. Other factors not directly related to surgical techniques, but which could influence intestinal cicatrization, have been less evaluated, such as the occurrence of hypovolemic shock.

Shock is defined as a circulatory dysfunction causing tissue hypoxia ${ }^{1}$. It can be secondary to various factors, among them, hypovolemia which is characterized as hemorrhagic shock. Because of low perfusion and tissue oxygenation, anaerobic metabolism develops and lactic acid is produced resulting in metabolic acidosis. Therefore, serum lactate has been used to evaluate the occurrence and intensity of tissue hypoperfusion ${ }^{2,3}$.

The compromise of the mucosal barrier of the gastrointestinal tract, secondary to shock, plays an important role in the breaking out of systemic repercussions, allowing the liberation of inflammatory measures, as well as bacterial translocation $^{4,5,6}$, which are factors that could interfere with the quality of intestinal anastomoses.

Hemorrhagic shock and the necessity to perform intestinal anastomoses are common occurrences in emergency surgeries and important events in post operative evolution.

The purpose of this study is to evaluate the influence of hemorrhagic shock in colonic anastomoses in rats, with a rupture by liquid distension resistance test.

\section{Methods}

This experiment was approved by the Committee of Ethics and Animal Experiments of the Campinas State University.

Wistar lineage rats (Rattus norvegicus albinos, Rodentia mammalian), averaging 90 days old and weighing from 310 to 380 grams were divided into 2 groups of 10, named: G1 and G2.

G1 - submitted to colonic anastomoses in normovolemia conditions

G2 - submitted to colonic anastomoses in hemorrhagic shock

The animals were submitted to venous anesthesia, with sixty milligrams $/ \mathrm{Kg}$ of $3 \%$ sodium pentobarbital and blood pressure measured before and during the whole surgical procedure with pressure transducer (Edwards) and registered on a polygraph.
A median laparotomy was performed, followed by a left colon section, two $\mathrm{cm}$ above the peritoneal reflection. Colonic anastomoses were performed with extra-mucosal seromuscular interrupted sutures with 7-0 polypropylene and protected by a four $\mathrm{cm}$ square of polyvinylchloride film (PVC), fixed to the pericolic fat.

In $\mathrm{G} 2$, the installation of shock was performed before the beginning of the surgical procedure by removing one half milliliter of blood from the carotid artery, every two minutes until the BP reached $50 \mathrm{mmHg}$ or the limit of $30 \%$ of total volemia. At the end of the surgical procedure, the fluid replacement was done through the carotid artery by using $0.9 \%$ physiological serum heated at $37^{\circ} \mathrm{C}$, corresponding to one third of the amount of blood removed. There was no fluid replacement in G1.

The dosage of lactate was done in both G1 and G2 before the installation of the hemorrhagic shock (ILG1/ILG2) and at the end of the surgery (FLG1/FLG2). The body temperature was maintained at $37^{\circ} \mathrm{C}$.

The rats were euthanized on the fifth post operative day and a five centimeter segment of the colon containing the anastomoses at its midpoint was resected from the abdominal cavity. Afterwards, it was placed in a recipient containing papaverine hydrochloride solution (250 milligrams/l) at a temperature of $37^{\circ} \mathrm{C}$ for 30 minutes.

The evaluation of the anastomoses was performed by a biomechanical rupture by liquid distension resistance test, as proposed by Chung ${ }^{7}$.

The colic segment was filled with physiological serum in a closed system, determining the intra-luminal pressure necessary to rupture the intestinal segment. The moment of rupture was seen by the leakage through the point of rupture and the corresponding pressure was registered on the polygraph (Bese).

\section{Statistic analysis}

In order to describe the profile of the sample according to the diverse variables, descriptive statistics were made (mean, standard deviation, minimum and maximum values) of the continuous variables, (G1 and G2). For the comparison of the continuous variables between the two groups the precision Mann-Whitney test was used and for the analysis of the lactate between the times the precision Wilcoxon test was used.

\section{Results}

\section{Evaluation of the abdominal cavity}

On the fifth post operative day, there were no macroscopical differences ly in the aspect of the abdominal cavity between the two groups; nor were there collection evidence, free liquid or perianastomotic blocks. In relation to the aspect of the, anastomoses good coaptation was observed in the borders and absence of ischemic signs in all of the rats of both groups. 
Mean arterial pressure (MAP)

The MAP values obtained of the two groups before, during and after the procedure are indicated in Table 1.

TABLE 1 - MAP Values

\begin{tabular}{|c|c|c|c|c|c|c|}
\hline G1 & $\begin{array}{c}\text { MAP } \\
\text { INITIAL } \\
\text { (mmHg) }\end{array}$ & $\begin{array}{c}\text { MAP } \\
\text { FINAL } \\
\text { (mmHg) }\end{array}$ & G2 & $\begin{array}{c}\text { MAP } \\
\text { INITIAL } \\
\text { (mmHg) }\end{array}$ & $\begin{array}{c}\text { MAP } \\
\text { 15Min. } \\
\text { (mmHg) }\end{array}$ & $\begin{array}{c}\text { MAP } \\
\text { FINAL } \\
\text { (mmHg) }\end{array}$ \\
\hline R1 & 105 & 101 & R1 & 110 & 53 & 49 \\
\hline R2 & 107 & 90 & $\mathbf{R 2}$ & 103 & 47 & 42 \\
\hline R3 & 106 & 86 & R3 & 105 & 52 & 58 \\
\hline R4 & 102 & 95 & R4 & 94 & 48 & 57 \\
\hline R5 & 119 & 99 & R5 & 98 & 47 & 58 \\
\hline R6 & 112 & 87 & R6 & 104 & 58 & 61 \\
\hline R7 & 94 & 75 & $\mathbf{R 7}$ & 106 & 49 & 62 \\
\hline R8 & 111 & 115 & R8 & 119 & 54 & 54 \\
\hline R9 & 115 & 115 & R9 & 121 & 57 & 76 \\
\hline R10 & 132 & 110 & R10 & 124 & 48 & 52 \\
\hline MEAN & 110.3 & 97.3 & MEAN & 108.4 & 51.3 & 56.9 \\
\hline
\end{tabular}

\section{Lactate serum}

The initial mean value of lactate serum of G1 and G2 are described in Table 2 and Figure 1.

TABLE 2 - Initial lactate serum (mmol/1) - G1 and G2

$\mathrm{p}>0.05$ (Mann-Whitney Test)

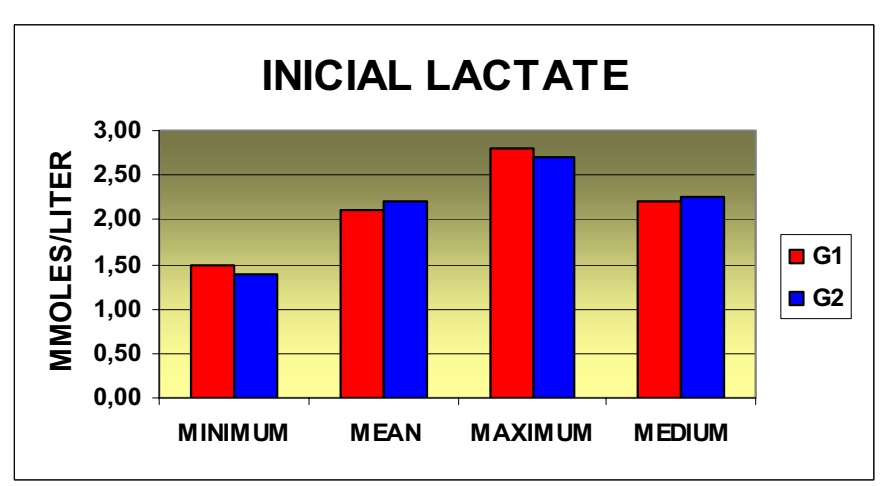

FIGURE 1
The comparative values of final lactate serum of G1 and G2 are presented in Table 3 and Figure 2

TABLE 3 - Final lactate serum (mmol/l) - G1 and G2

\begin{tabular}{ccccccc}
\hline GROUP & N & MEAN & DP & MAX. & MEAN & MIN. \\
\hline FLG1 & 10 & 1.91 & 0.67 & 3.10 & 1.75 & 0.90 \\
FLG2 & 10 & 3.69 & 0.68 & 4.90 & 3.80 & 2.50 \\
\hline $\mathrm{p}<0.005$ (Mann-Whitney Test) & & & &
\end{tabular}

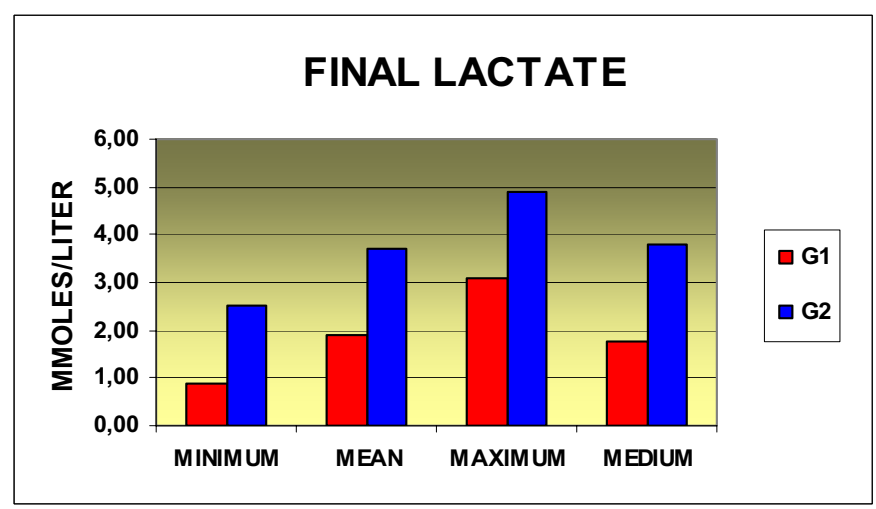

FIGURE 2 
Initial and final dosage of lactate serum in G1

The comparative mean values of the initial (ILG1) and final FLG1) lactate serum dosages in G1 are shown in Table 4 and Figure 3.

TABLE 4 - Lactate serum - initial and final (mmol/1) - G1

\begin{tabular}{ccccccc}
\hline LACTATE & N & MEAN & DP & MAX. & MEAN & MIN. \\
\hline ILG1 & 10 & 2.1 & 0.47 & 2.80 & 2.20 & 1.50 \\
FLG1 & 10 & 1.91 & 0.67 & 3.10 & 1.75 & 0.90 \\
\hline
\end{tabular}

$\mathrm{p}>0.05$ (Wilcoxon Test)

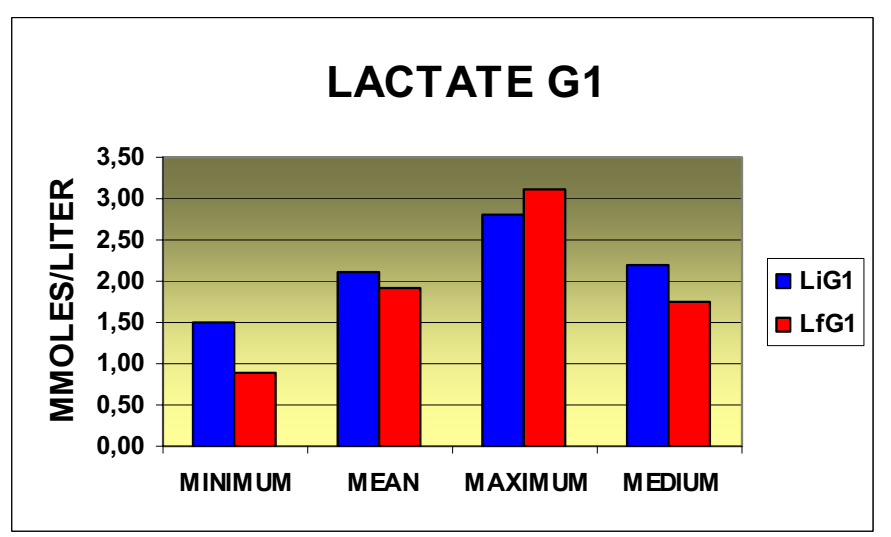

FIGURE 3

\section{Initial and final dosage of lactate serum in G2}

In $\mathrm{G} 2$, the initial mean value of lactate serum (ILG2) was smaller than the final mean value. (FLG2) $(p<0,01)$. (Table 5 and Figure 4).

TABELA 5 - Initial lactate serum, after 15 minutes and final $(\mathrm{mmol} / \mathrm{l})-\mathrm{G} 2$

\begin{tabular}{ccccccc}
\hline LACTATE & N & MEAN & DP & MAX. & MEAN & MIN. \\
\hline ILG2 & 10 & 2.21 & 0.37 & 2.70 & 2.25 & 1.40 \\
IL5G2 & 10 & 3.32 & 0.85 & 4.50 & 3.20 & 1.80 \\
FLG2 & 10 & 3.69 & 0.68 & 4.90 & 3.80 & 2.50 \\
\hline
\end{tabular}

$\mathrm{p}<0.0001$ (Friedman Test)

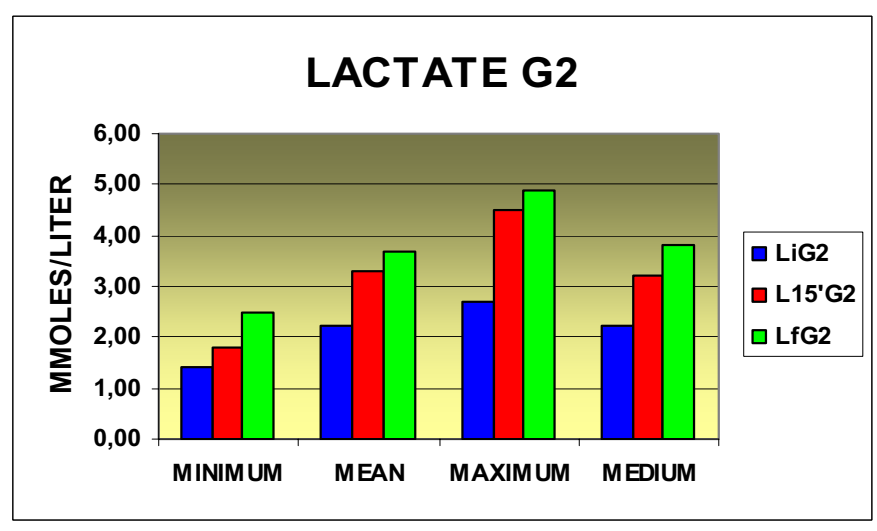

FIGURE 4

\section{Rupture resistance test by liquid distension}

No difference was observed between the mean values of rupture in G1 and G2 (Table 6 and Figure 5).

TABLE 6 - Rupture pressure (millimeters of mercury) - G1 and G2

\begin{tabular}{ccccccc}
\hline GRUPO & N & MEAN & DP & MAX. & MEAN & MIN. \\
\hline G1 & 10 & 160.7 & 29.7 & 206.0 & 164.5 & 115.0 \\
G2 & 10 & 152.1 & 23.6 & 204.0 & 152.0 & 118.0 \\
\hline
\end{tabular}

$\mathrm{p}>0.05$ (Mann-Whitney Test)

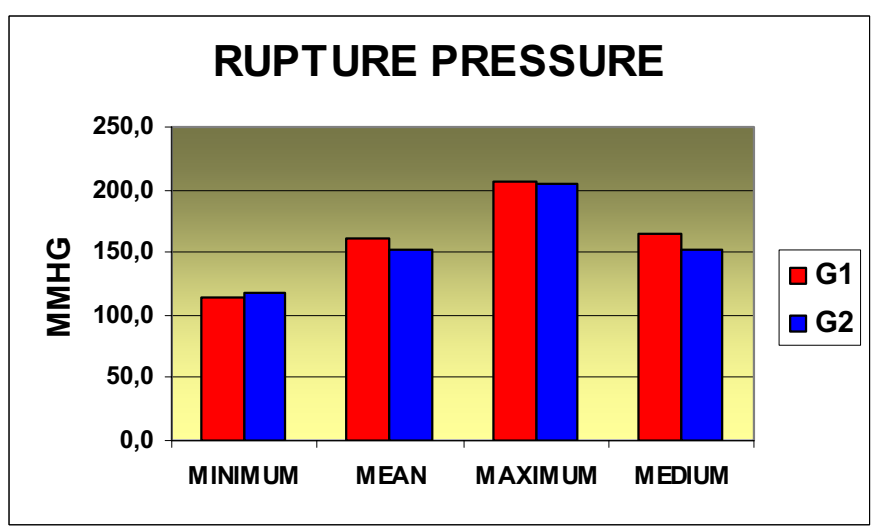

FIGURE 5

\section{Discussion}

Anastomotic dehiscence stands out among the most serious post operative complications in gastrointestinal surgery, especially in colon surgery, be it precocious or happening later on, with a high mortality rate. This complication can be attributed to a series of factors such as gastrointestinal disease itself, inadequate blood flow, tension of the sutures or technical failure.

Actually, the number of patients with traumas that aggravate hemorrhagic shock. is notable. Therefore, the simultaneous occurrence of intestinal injuries in patients in critical condition, make it relevant and the anastomotic dehiscence contributes to the death rate. Besides this, the intestinal tract is one of the organs that precociously suffers the consequences of the mechanism of post-shock hemorrhagic ischemia ${ }^{8}$, causing the release of inflammatory cytokines, toxins and bacterial translocation with serious systemic repercussions and, it is believed, that these alterations can negatively influence intestinal anastomoses. $^{3}$

Considering ethical and practical aspects in the evaluation of this variable, the influence of the state of hemorrhagic shock in patients with intestinal anastomoses, a study model in animals has been elaborated. The model of hypovolemic shock developed was obtained by the removal of half millimeter of blood until the $50 \mathrm{mmHg}$ mean arterial pressure value is reached or when the corresponding volume of $30 \%$ of the total volume of the rat is reached. The limit of $30 \%$ was chosen for two reasons: to simulate the human condition of moderate non- 
lethal hemorrhagic shock and due to the fact that the rats tolerate well this loss of volume according to a previous pilot project.

The replacement volume corresponded to the $30 \%$ of the volume removed, percentage established as the least amount necessary to decrease mortality, without the restoration of the initial arterial blood pressure.

Basically, two parameters were used to evaluate the shock level: mean arterial pressure and lactate serum dosage. Although the mean arterial pressure was not the most reliable parameter, since there are compensating mechanisms, it was used because we were dealing with one of the most used parameters in clinical practice. As shown by Gilmour et $a l^{9}$ in an experimental model, the $10 \%$ volemic reduction, in spite of not being accompanied of significant alterations in arterial pressure, caused a significant reduction in blood flow (28\%) in the colon, as well as a $29 \%$. decrease of oxygen supply This being so, in this study, in which the development of a state of shock occurs with the removal of $30 \%$ volemia or maintaining the MAP values of $50 \mathrm{mmHg}$, it can be assumed that oxygen tissue supply in G2 had been compromised.

The evaluation of the intensity of hemorrhagic shock can be done through the dosage of lactate serum. The excess of lactate, as an indicator of the lack of oxygen, has been studied to evaluate the seriousness of the state of shock in humans and in experimental models ${ }^{2,3}$. It is considered a quite reliable parameter for shock intensity when comparing the measurements of arterial pressure and heart insufficiency ${ }^{10,11}$. Considering that in G2 the values of the initial and final doses of lactate serum were statistically significant among them, as well as when compared to G1 values, the experimental model developed in this study simulates a non lethal shock condition, which effectively indicated that the anastomoses in G2 rats were in unfavorable conditions in relation to those of G1.

However, in this study, there was no evidence that the anastomoses of G1 animals was compromised by the rupture by liquid distension resistance test. Dzienis-Koronkiez et al ${ }^{12}$ found evidence of distinct alterations of the colon and small intestine in rats which underwent the hemorrhagic shock. The liberation of proteolytic enzymes, particularly cathepsina D, was higher than the proximal portions of the small intestine. These findings suggest a greater susceptibility of structural compromise of the small intestine in relations to the colon, as has been observed by other authors ${ }^{13,14,8}$. This way, colic anastomoses carried out under adverse conditions could be more resistant, becoming in just a few alterations into biomechanic parameters.

In the present study, as it was observed by BuchnillerCrair TL et $a l^{14}$, no alterations were noted in the rupture pressure of the anastomoses during the first post-operative week. However, the histological alterations that could be associated to the weakness of anastomoses accentuated after the first postoperative week ${ }^{13,14}$. One may suppose that the major incidence of anastomotic dehiscence of, as well as the evidence of lesser values of rupture pressure, can occur principally after the seventh post operative day.

The present experiment can contribute to better understanding of the other variables which can influence the quality of intestinal anastomoses. The fact that the values of rupture pressure by liquid distension would not have been different between the two groups, permits the inference that the presence of hypovolemic shock does not interfere in any significant manner in the colonic anastomoses in rats in the early post operative phases. The histological alterations observed in other studies do not appear to be sufficient to weaken the sutures in the first post operative week.

The intensity and duration of the shock as well as the post operative period should be taken into consideration for the interpretation of the evaluation of the anastomoses.

\section{Conclusion}

The presence of hemorrhagic shock causes no harmful effects on colonic anastomoses in rats evaluated with the rupture by liquid distension resistance test, on the fifth post operative day.

\section{References}

1. Mantovani M, Filho AC. Caracterização, avaliação e monitorização dos estados de choque no trauma. In: Silva MR. Choque. São Paulo: Atheneu; 1996. p.173-87.

2. Dunham CM, Siegel JH, Weireter L, Fabian M, Goodarzi S, Guadalupi P, et al. Oxygen debt and metabolic academia as quantitative predictors of mortality and the severity of the ischemic insult in hemorrhagic shock. Crit Care Med. 1991,19(2):231-43.

3. Knotzer H, Pajak W, Maier S, Dünser MW, Ulmer H, Schwarz $\mathrm{B}$, et al. Comparison of lactated Ringer's, gelatine and blood resuscitation on intestinal oxygen supply and mucosal tissue oxygen tension in haemorrhagic shock. Br J Anaesth. 2006;97(4):509-16.

4. Chang TW. Improvement of survival from hemorrhagic shock by enterectomy in rats: finding to implicate the role of the gut for irreversibility of hemorrhagic shock. J Trauma. 1997,42(2):223-30.

5. Collins AS. Gastrointestinal complications in shock. Crit Care Nurse Clin North Am 1990;(2):269-77.

6. Haglund U. The splanchnic organs as the source of toxic mediators in shock. Prog Clin Biol Res. 1988;264:135-45.

7. Chung WF. Estudo da ação de aderências sobre anastomose cólica: trabalho experimental em ratos [Tese - Mestrado]. Campinas: Universidade Estadual de Campinas; 2000.

8. Chang JX, Chen S, Ma LP, Jiang LY, Chen JW, Chang RM, et al. Functional and morphological changes of the gut barrier during the restitution process after hemorrhagic shock. World J Gastroenterol. 2005; 11(35):5485-91.

9. Gilmour DG, Aitkenhead AR, Hothersall AP, Ledingham IMcA. The Effect of hipovolaemia on colonic blood flow in the dog. Br J Surg. 1980;67:82-4.

10. Yilmaz EN, Vahl AC, van Rij GL, Vink GQ, Lange-De KlerknES, Brom HL, Rauwerda JA. The rennin-angiotensin system in swine during hypovolaemic shock combined with lowflow ischemia of the sigmoid colon. Cardiovasc Surg. 1999;7(5):539-44.

11. Rixen D, Raum M, Holzgraefe B, Sauerland S, Nagelschmidt M, Neugebauer EA. A pig hemorrhagic shock model: oxygen 
debt and metabolic academia as indicators of severity. Shock. 2001,16(3):229-44.

12. Dzienis-Koronkiewicz E, Debek W, Chyczewski L. Hemorrhagic shock-induced changes in the cathepsin D activity in the intestinal wall and blood serum in rats. Eur J Pediatr Surg. 1998;8(5):288-94.

13. Baffa LP, Garcia RLS, Campos AD, Rocha JJR, Feres O. Efeito da anemia aguda na cicatrização de anastomoses colônicas: estudo experimental em ratos. Rev Bras Coloproctol. 2005;25(1):24-30.
14. Buchmiller-Crair TL, Kim CS, Won NH, Chopourian HL, Shaw KS, Fonkalsrud EW. Effect of acute anemia on the healing of intestinal anastomoses in the rabbit. J Trauma. 2001;51:363-8.

\section{Acknowledgements}

To Ana Cristina de Moraes and William Adalberto Silva at the Medicine Center and Experimental Surgery, University of Campinas (UNICAMP) for their technical support.

\section{Correspondence:}

Rua Fortunato Basseto, 490

13465-000 Americana - SP Brazil

Phone: (55 19)3407-5667

Received: November 23, 2007

aypereira@uol.com.br

Review: January 15, 2008

Accepted: February 12, 2008

\section{How to cite this article}

Pereira YEA, Fagundes JJ, Morandini RC, Ayrizono MLS, Nascimento RB, Leal RF, Góes JRN, Mantovani M, Coy CSR. Hemorrhagic shock influence on colonic anastomoses in rats. Evaluation of rupture resistance test by liquid distension. Acta Cir Bras. [serial on the Internet] 2008 May-June;23(3). Available from URL:http://www.scielo.br/acb

\section{*Color figures available from www.scielo.br/acb}

